\title{
Magnetizer Device
}

National Cancer Institute

\section{Source}

National Cancer Institute. Magnetizer Device. NCI Thesaurus. Code C50041.

A device designed to make another object magnetic. 